\title{
Upaya Meningkatkan Hasil Belajar Smash Bola Voli Siswa Kelas X SMK Negeri 5 Tanjab Barat Melalui Pendekatan Gaya Mengajar Latihan Power Tungkai Dengan Menggunakan Modifikasi Bola Gantung
}

\author{
Sukendro ${ }^{1}$, Ekawarna ${ }^{2}$, Fajar Dwirahayu ${ }^{3}$, Ely Yuliawan ${ }^{4}$ \\ ${ }^{1,2,3}$ Program Studi Magister Teknologi Pendidikan, ${ }^{4}$ FKIP Universitas Jambi \\ sukendrodasar@yahoo.co.id,eka.warna@unja.ac.id,fajardwirahayu92@gmail.com, \\ elyyuliawan.fik@unja.ac.id
}

\begin{abstract}
Abstrak: Tujuan penelitian ini adalah mengkaji penerapan gaya mengajar latihan untuk meningkatkan hasil belajar Smash bola voli dan melihat peningkatan proses belajar mengajar dengan cara mengamati secara sistematik gerakan atau pokok bahasan dari teman serta melihat peningkatan keterampilan siswa dalam memperaktikkan teknik dasar smash bola voli dengan baik dan benar sekaligus memberikan kemudahan bagi siswa dan guru dalam menjalankan proses belajar mengajar bola voli. Metode penelitian yang digunakan adalah metode Penelitian Tindakan Kelas (Classroom Action Research) dengan pengambilan data kualitatif dan kuantitatif. Penelitian ini dilakukan dalam dua siklus dan pada siklus ke pertama motivasi siswa cukup meningkat sesuai dengan rencana pembelajaran, hasilnya adalah 22 siswa aktif, 8 siswa kurang dan 3 siswa pasif. Berdasarkan hasil diatas pada siklus ke 1 siswa cukup antusias dalam mengikuti pembelajaran Smash bola voli. Sesuai dengan refleksi, harapan dari peneliti $66,7 \%$ siswa aktif, termotivasi, serta antusias dalam mengikuti kegiatan pembelajaran. Sehingga penilitian harus dilakukan pada tahap siklus kedua. Siklus kedua peneliti berhasil memperbaiki pendekatan pembelajaran dengan memotivasi siswa sesuai dengan kondisi siswa pada saat itu, hasilnya adalah 30 siswa aktif dalam mengikuti pembelajaran passing atas bola voli, 3 siswa bersikap kurang aktif. Berdasar hasil belajar siswa pada siklus pertama nilai rata-rata kelas pembelajaran smash bola voli adalah 73,48 dan hasil belajar siswa pada siklus kedua adalah 79,76 .
\end{abstract}

Kata Kunci : Hasil Belajar, Bola Gantung

\section{Efforts to Improve Learning Outcomes of Volleyball Smash Students Grade X SMK Negeri 5 Tanjab Barat Through Teaching Style Approach Exercises Power Limbs Using Modifications Hanging Balls}

\begin{abstract}
The purpose of this study is to examine the application of teaching style exercises to improve the learning outcomes of Smash volleyball and see the improvement of the teaching and learning process by systematically observing the movements or subjects of friends and see the improvement of students' skills in practicing the basic techniques of smash volleyball properly and correctly while providing convenience for students and teachers in carrying out the learning process of teaching volleyball. The research method used is the classroom action research method with qualitative and quantitative data retrieval. The study was conducted in two cycles and in the first cycle the motivation of students was quite increased according to the learning plan, the result was 22 active students, 8 fewer students, and 3 passive students. Based on the above results in the 1st cycle students are quite enthusiastic about participating in the learning of Volleyball Smash. By the reflection, the expectations of the researchers $66.7 \%$ of students are active, motivated, and enthusiastic in participating in learning activities. So the research should be done at the second stage of the cycle. The second cycle of researchers managed to improve the learning approach by motivating students according to the condition of the students at the time, the result was 30 students were active in following the learning passing over volleyball, 3 students were less active. Based on student
\end{abstract}


learning outcomes in the first cycle, the average grade of the volleyball smash learning class was 73.48 and the student's learning outcome in the second cycle was 79.76.

Keywords: Learning Outcomes, Hanging Balls

\section{PENDAHULUAN}

Bola Voli merupakan salah satu cabang olahraga yang banyak digemari semua lapisan masyarakat di Indonesia. Olahraga ini dapat dimainkan mulai dari tingkat anak-anak sampai orang dewasa, baik pria maupun wanita. Pada awal mulanya bermain bola voli untuk tujuan rekreasi untuk mengisi waktu luang atau sebagai selingan setelah lelah bekerja atau belajar. Selain tujuan-tujuan tersebut banyak orang berolahraga khususnya bermain voli untuk memelihara dan meningkatkan kesegaran jasmani atau kesehatan. Kemudian berkembang ke arah tujuan yang lain, seperti tujuan prestasi yang tinggi untuk meningkatkan prestasi diri, mengharumkan nama daerah, bangsa, dan negara (Asep Kurnia, 2007: 14).

Selanjutnya untuk memperoleh hasil yang memuaskan dalam permainan Bola Voli, diperlukan penguasaan teknik dasar. Sarumpaet (1991: 133) menyatakan bahwa penguasaan teknik dasar bola voli merupakan unsur yang menentukan kalah dan menangnya regu dalam pertandingan. Oleh karena itu, teknik dasar permainan harus benar-benar dikuasai lebih dahulu agar dapat mengembangkan untuk pertandingan lancar dan teratur. Penguasaan teknik-teknik dasar yang baik merupakan awal dari taktik permainan yang baik pula. Teknik dasar bola voli yang harus dikuasai oleh setiap pemain adalah teknik dasar servis, teknik dasar passing, teknik dasar smash, dan teknik dasar blocking.

Pengalaman dilapangan mengajarkan kompetensi Bola Voli dengan sub kopetensi smash ternyata banyak siswa yang mengalami kesulitan/kegagalan. Hal ini dapat dilihat dari hasil pengamatan, tidak semua siswa dapat melakukan smash dalam permainan Bola Voli dengan tingkat keberhasilan baik. Penguasaan teknik dasar permainan Bola Voli harus benar-benar diperhatikan dan dilaksanakan, sebab penguasaan teknik dasar permainan Bola Voli merupakan salah satu unsur yang turut menentukan menang kalahnya suatu regu dalam pertandingan, disamping kondisi fisik, taktik dan mental. Salah satu teknik dasar yang paling utama dalam permainan Bola Voli ini adalah teknik dasar smash karena teknik ini merupakan cara yang paling efektif dalam memasukkan bola ke daerah lawan.

Beberapa faktor yang menentukan keberhasilan seseorang dalam melakukan smash adalah timing dan ketepatan, meliputi: ketepatan saat melakukan awalan, ketepatan saat meloncat, ketepatan saat memukul bola dan mendarat. Hal ini berarti bahwa dalam pembinaan pada tahap-tahap awal perlu ditekankan untuk penguasaan teknik-teknik dasar Smash. Akan tetapi teknik Smash merupakan teknik yang paling sulit dilakukan terutama pada siswa SMK Negeri 5 Tanjab Barat, mulai dari melakukan tahap awalan, lompatan, memukul bola, hingga mendarat, siswa masih banyak yang kaku dalam melakukan gerakan-gerakan tersebut.

Metode dalam pembelajaran sangat berpengaruh terhadap keberhasilan proses belajar. Keberhasilan suatu pembelajaran sangat dipengaruhi oleh, metode, guru, siswa dan sarana prasaranan yang tersedia. Berkaitan dengan hal itu diharapkan para guru dapat mencari dan menciptakan metode yang sesuai dengan situasi dan kondisi siswa maupun peralatan yang tersedia, sehingga proses pelatihan dapat berlangsung sesuai dengan yang diharapkan.

Kecakapan guru dalam menyampaikan tujuan pembelajaran harus dapat membangkitkan motivasi, dan juga bisa mengevaluasi serta dapat menganalisa hasil pembelajaran. Kemampuan guru sendiri dalam menguasai materi sangat berpengaruh terhadap tingkat keberhasilan. Siswa juga harus diperhatikan akan tingkat kebugaran jasmaninya, bakat dan minat, tingkat kecerdasan dan jenis kelamin, selain itu tersedianya sarana dan prasarana yang mencukupi, dengan alat yang cukup akan memberi kesempatan anak untuk dapat melakukan latihan lebih banyak.

Belajar merupakan kegiatan sehari-hari bagi siswa sekolah. Kegiatan ini dilakukan secara sadar dan terencana yang mengarah pada pencapaian tujuan dari kegiatan belajar yang sudah dirumuskan dan ditetapkan sebelumnya. Keberhasilan dalam belajar terlihat dari siswa yang berprestasi. Keberhasilan siswa dalam belajar tidak terlepas dari peran guru yang mampu memberi motivasi dan dapat menciptakan iklim belajar yang harmonis menyenangkan dan kondusif, sehingga terjadi interaksi dalam proses pelaksanaan belajar mengajar. Belajar adalah suatu proses perubahan tingkah 
laku sebagai akibat adanya interaksi antara individu dengan lingkungannya. Tingkah laku itu mencakup aspek pengetahuan, keterampilan, dan sikap (Husdarta 2:2000).

Belajar dan mengajar merupakan dua pengertian atau dua konsep yang satu sama lain tidak bisa dipisahkan, keduanya saling berkaitan, saling berhubungan dan saling mempengaruhi. Belajar pada hakikatnya adalah suatu kegiatan yang dilakukan oleh seseorang (anak/murid/siswa) dalam usahanya untuk memperoleh berbagai pengalaman hingga menghasilkan perubahan tingkah laku pada dirinya. Perubahan tingkah laku yang terjadi pada diri seseorang sebagai hasil dari proses belajar, dapat ditunjukan dalam berbagai bentuk seperti berubah dalam bentuk pengetahuannya, berubah dalam bentuk nilai dan sikapnya, berubah dalam bentuk keterampilannya (kognitif, afektif, psikomotor). Sedangkan mengajar pada hakikatnya adalah suatu kegiatan yang dilakukan oleh seseorang atau tim (guru/pendidik) dalam usahanya untuk membantu seseorang atau kelompok yang sedang belajar agar memperoleh berbagai pengalaman yang diharapkannya.

Menurut Martinis (2007: 59), proses belajar mengajar merupakan proses yang sistematik, artinya proses yang dilakukan oleh guru dan siswa di tempat belajar dengan melibatkan sub-sub, bagian, komponen-komponen atau unsur-unsur yang saling berinteraksi untuk mencapai suatu tujuan. Proses belajar yang menyenangkan menjadikan siswa lebih aktif dalam melakukan proses pembelajaran. Hal yang dapat menyenangkan siswa biasanya pembelajaran yang melibatkan media ataupun dengan bantuan berupa alat.

Gerlach dan Ely (Azhar Arsyad, 2011: 3) menjelaskan bahwa "media dapat dipahami secara garis besar meliputi manusia, materi, atau kejadian yang membangun kondisi yang membuat siswa mampu memperoleh pengetahuan, keterampilan atau sikap". Berdasarkan pengertian tersebut guru, buku teks, dan lingkungan sekolah dimaksudkan sebagai media. Lebih khusus media dalam pembelajaran lebih cenderung diartikan sebagai alat-alat grafis, photografis dan elektronik untuk menangkap, memproses, dan menyusun kembali informasi visual atau verbal.

Media pembelajaran adalah segala sesuatu yang dapat menyampaikan dan menyalurkan pesan dari sumber secara terencana sehingga tercipta lingkungan belajar yang kondusif dimana penerimanya dapat melakukan proses belajar secara efisien dan efektif. Sesuai pendapat-pendapat tersebut dapat disimpulkan media pembelajaran merupakan alat yang digunakan untuk menyalurkan pesan dari sumber belajar yaitu buku atau modul dan sumber belajar lainnya kepada penerima yaitu siswa, agar tercipta lingkungan berlajar yang kondusif, efisien, dan menyenangkan (Yudhi, 2013: 7)

Media adalah suatu ekstensi manusia yang memungkinkannya mempengaruhi orang lain yang tidak mengadakan kontak langsung dengan dia. Nilai praktis media pembelajaran antara lain yaitu dapat membangkitkan minat dan motivasi belajar siswa. Disamping itu, media pembelajaran memiliki kelebihan yang dapat mengatasi keragaman latar belakang siswa, sehingga dapat memberikan suatu pengertian yang sama kepada siswa tentang suatu materi pelajaran. Menurut Oemar (1994:12) media pembelajaran adalah alat, metode dan teknik yang digunakan dalam rangka lebih mengefektifkan komunikasi dan interaksi antara guru dan siswa dalam proses pendidikan dan pengajaran di sekolah.

Bola digantung merupakan salah satu media yang dapat digunakan sebagai perantara untuk mentransfer dalam menyampaikan pesan dari pengirim ke penerima khususnya pada media latihan teknik pukulan Smash pada bola voli. Bola digantung yang dimaksud dalam pengertian ini adalah bola yang digantung dengan seutas tali yang diikat pada ujung tiang yang berporos pada pengikat tali, dengan menggunakan bola voli pada ketinggian sesuai dengan jangakauan pemain.

Latihan memukul bola digantung secara mekanik mampu mengembangkan kecepatan dan ketepatan memukul bola. Dengan awalan langkah serta ketepatan memukul bola yang dilakukan secara berulang-ulang dapat melatih respon memukul bola yang pas dan dapat melatih agar mencapai raihan bola yang tinggi serta lompatan yang tinggi pula. 


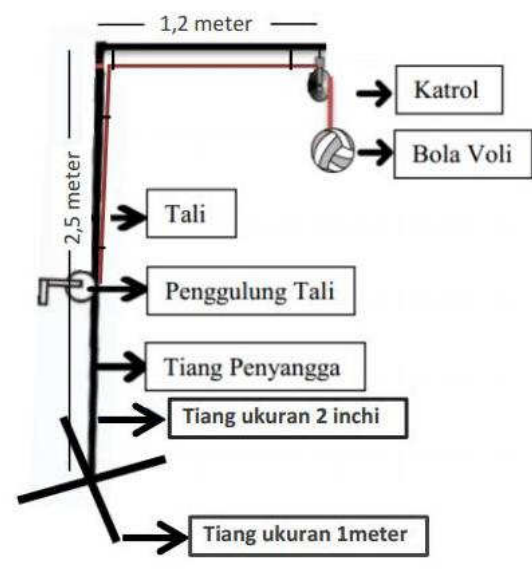

Gambar 1. Modifikasi alat penggantung Bola Voli

\section{METODE}

Metode penelitian yang digunakan adalah metode Penelitian Tindakan Kelas (Classroom Action Research) dengan pengambilan data kualitatif dan kuantitatif, pelaksanaan penelitian melibatkan rekan sejawat sebagai kolaborator. Terlihat pada gambar 1 model yang digunakan pada penelitian ini.

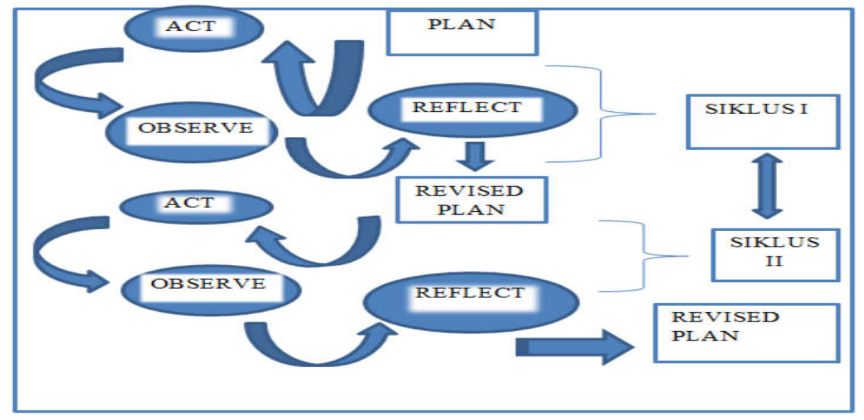

Gambar 2. Model Action Reseach Kemmis \& Taggart (Ekawarna 2013:20)

Data yang diperoleh dalam penelitian ini melalui observasi dan pengamatan serta tes hasil belajar siswa yang dituliskan dalam suatu format. Untuk mengecek keabsahan data penelitian, dilakukan oleh peneliti bersama kolaborator. Teknik pengumpulan data yang diterapkan dalam penelitian ini adalah sebagai berikut: (1) melakukan observasi atau pengamatan yang merupakan suatu teknik atau cara mengumpulkan data dengan jalan mengadakan pengamatan terhadap kegiatan belajar mengajar, dengan menggunakan pedoman observasi, (2) studi dokumentasi merupakan suatu teknik pengumpulan data dengan menghimpun dan menganalisis dokumen-dokumen, baik dokumen tertulis, gambar maupun elektronik, (3) menyiapkan lembar evaluasi, hal ini dilakukan untuk mengetahui tingkat keberhasilan prestasi belajar siswa.

Pada penelitian ini, teknik yang digunakan dalam menganalisis data yang terkumpul dilakukan dengan mencari sumber data dalam penelitian yaitu siswa dan tim peneliti, dengan jenis data kuantitatif diperoleh langsung dari observasi dan pengamatan sebelum dan sesudah dilakukan tindakan berupa proses pengajaran teknik dasar Smash Bola Voli pada siswa kelas X dengan menerapkan gaya mengajar latihan power tungkai dan modifikasi bola gantung dalam proses pembelajaran. Penelitian ini dikatakan berhasil apabila: (1) sebagian besar (80\%) siswa merasa senang dan aktif dalam proses 
pembelajaran Smash bola voli pada siswa kelas X, (2) hasil belajar siswa meningkat dalam pembelajaran Smash bola voli pada siswa kelas X dengan penerapan gaya mengajar latihan dalam proses pembelajaranya, (3) siswa dapat bersosialisasi secara baik dengan siswa lain dan guru, (4) siswa dapat menilai gerakan yang benar dan salah pada saat proses pembelajaran, serta mampu melakukan gerakan smash bola voli dengan benar, (5) guru melayani siswa dengan beragam, (6) siswa menjadi termotivasi untuk mengikuti proses pembelajaran smash bola voli pada siswa kelas X, (7) terjadi interaksi yang kondusif antara siswa dengan siswa, maupun guru dengan siswa, (8) Suasana belajar mengajar kondusif dan menyenangkan siswa.

Penilaian terhadap kemampuan siswa dalam melakukan smash bola voli, dengan kriteria: Skor 4 = gerakan sangat sempurna, skor 3 = gerakan sempurna, skor 2 = gerakan hampir sempurna, dan skor 1 = gerakan kurang sempurna. Jumlah skor maksimal adalah 28. Skor penilaian indikator Smash bola voli terdiri dari 7 aspek pada isntrumen penilaian, dihitung nilai persentase dengan rumus sebagai berikut:

$$
\text { Nilai }=\frac{\text { Jumlah skor yang diperoleh }}{\text { Jumlah skor maksimal }} \times 100
$$

Persentase ketuntasan belajar $=\underline{\text { Jumlah sisiwa tuntas belajar }}$ X 100

Jumlah seluruh siswa

Nilai Kriteria Belajar Minimal $=75$ dan persentase ketuntasan kelas $=80 \%$

\section{HASIL DAN PEMBAHASAN}

Berdasarkan hasil penelitian pada siklus 1 maka dapat diambil kesimpulan bahwa sebanyak 11 siswa sekitar $(33,3 \%)$ siswa belum mampu melakukan gerakan smash bola voli, atau dengan kata lain belum mencapai batas ketuntasan minimal nilai 75 . Sedangkan siswa yang sudah mencapai batas ketuntasan sejumlah 22 siswa $(66,7 \%)$. Hasil ketuntasan belajar disajikan pada tabel dan gambar berikut:

Tabel 1. Hasil ketuntasan belajar smash bola voli siklus 1

\begin{tabular}{ccccc}
\hline No & Ketuntasan & KBM & F & \% \\
\hline 1. & Lulus & $>75$ & 22 & 66,7 \\
\hline 2. & Tidak Lulus & $<75$ & 11 & 33,3 \\
\hline & Jumlah & & $\mathbf{3 3}$ & $\mathbf{1 0 0}$ \\
\hline
\end{tabular}

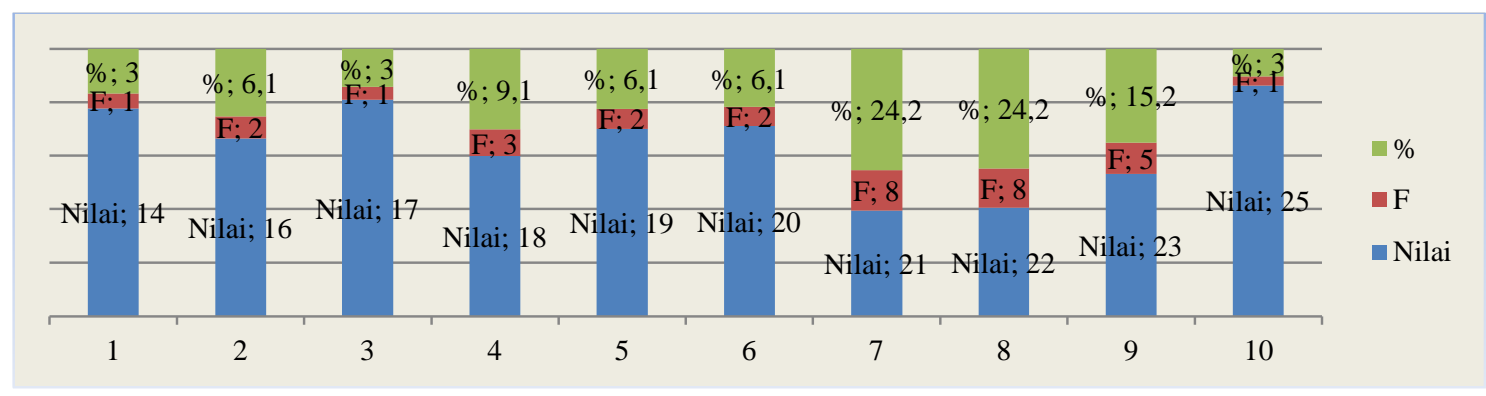

Gambar 3. Hasil Belajar Smash bola voli Siklus 1 
Berdasarkan Tabel 1 di atas, maka dapat diambil kesimpulan bahwa sebanyak 3 siswa sekitar (9\%) siswa belum mampu melakukan gerakan smash bola voli, atau dengan kata lain belum mencapai batas ketuntasan minimal nilai 75. Sedangkan siswa yang sudah mencapai batas ketuntasan sejumlah 30 siswa $(91,1 \%)$. Hasil ketuntasan belajar disajikan pada tabel dan gambar berikut:

Tabel 2. Hasil ketuntasan belajar smash bola voli siklus 2

\begin{tabular}{ccccc}
\hline No & Ketuntasan & KBM & F & \% \\
\hline 1. & Lulus & $>75$ & 30 & 91,1 \\
\hline 2. & Tidak Lulus & $<75$ & 3 & 9 \\
\hline & Jumlah & & $\mathbf{3 3}$ & $\mathbf{1 0 0}$ \\
\hline
\end{tabular}

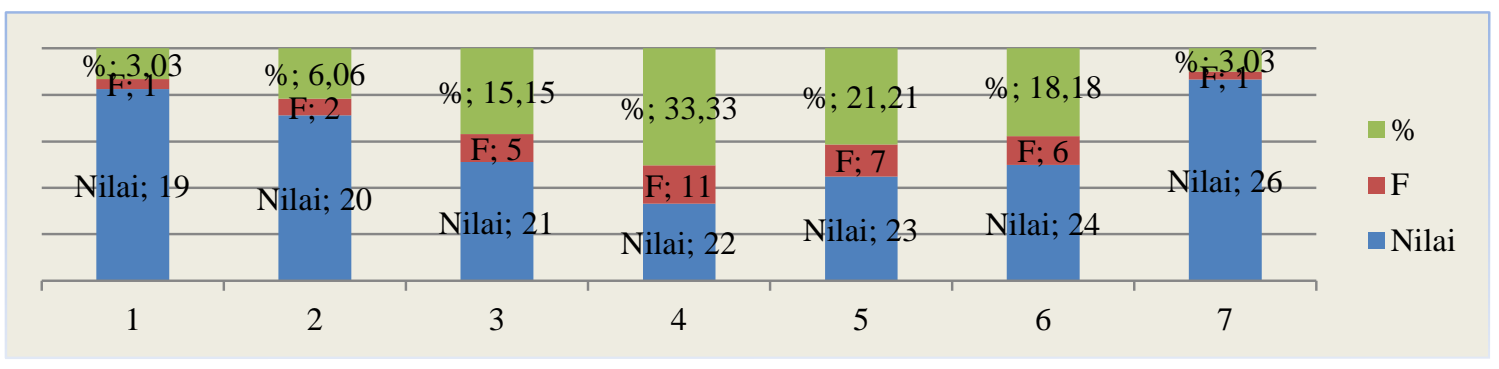

Gambar 4 Hasil Belajar Smash bola voli Siklus 2

Dari hasil penelitian diperoleh rata-rata presentase hasil belajar siswa melalui pendekatan gaya mengajar latihan power tungkai dengan menggunakan modifikasi bola gantung pada siklus I dan siklus II dapat dilihat pada tabel di bawah ini:

Tabel 3 Rata-rata Presentase Hasil Belajar Siswa Pada Siklus I dan Siklus II

\begin{tabular}{|c|c|c|c|}
\hline No. & Indikator & Siklus 1 & Siklus 2 \\
\hline 1 & Rata-rata & 73,48 & 79,76 \\
\hline 2 & Skor tertinggi & 89,3 & 92,9 \\
\hline 3 & Skor terendah & 50 & 67,9 \\
\hline 4 & Tingkat Ketuntasan & $64 \%$ & $91,1 \%$ \\
\hline
\end{tabular}

Pembahasan setiap indikator aktivitas belajar siswa saat pembelajaran pada siklus I dan siklus II sebagai berikut:

1) Siswa berdiri menghadap net dengan jarak 3 langkah. Pada siklus I sebesar 67,4\%. Pada awal siklus I beberapa siswa belum fokus dan tidak memperhatikan guru dalam menyampaikan materi pembelajaran sehingga saat pelaksanaan siswa masih banyak berdiri kurang dari 3 langkah bahkan tidak menghadap ke net. Pada siklus II hasil belajar siswa meningkat dari siklus I sebelumnya yaitu $75 \%$, peningkatan tersebut menandakan bahwa target yang diharapkan telah tercapai, karena hasil rata-rata siklus II lebih baik dibandingkan dengan siklus I. 
2) Siswa melakukan awalan dengan langkah lebar dan datar serta melakukan tolakan dengan sekuat tenaga menggunakan kedua kaki. Pada siklus I masih banyak siswa yang melakukan langkah yang cukup kecil dan melompat tidak sekuat tenaga sehingga lompatan tidak terlalu tinggi, gerakan pada siklus I ini sebanyak 75\%. Guru melakukan perbaikan dengan lebih memahami kesulitan gerakan pada siswa. Guru melakukan contoh berulang-ulang. Pada siklus II keberanian siswa dalam melakukan gerakan meningkat dibandingkan dengan siklus I, yaitu diperoleh rata-rata sebanyak $81,1 \%$.

3) Kedua lengan di ayunkan kebelakang dan pandangan kearah bola.

Pada siklus I, gerakan siswa berupa ayunan kedua lengan dan pandangan kearah bola sebesar $71,2 \%$. Masih terlihat kesulitan siswa dalam melakukan ayunan lengan dan mengarahkan pandangan kearah bola. Guru memberikan contoh yang berulang-ulang dengan arah pandangan bola yang digantung. Pada siklus II guru berhasil meningkatkan kemampuan gerakan tersebut dengan hasil rata-rata persentase sebanyak $78 \%$.

4) Ayunkan lengan yang akan memukul ke depan dan punggung melenting ke belakang. Pada pertemuan siklus I hasil rata-rata yang diperoleh adalah sebanyak $87,9 \%$. Hal tersebut menurun dengan hasil ratarata pada siklus II, artinya pada siklus dua mengalami penurunan. Meskipun demikian hasil rata-rata yang diperoleh pada siklus II cukup baik. Hal tersebut dikarenakan siswa lebih fokus dalam melakukan gerakan sebelumnya. Untuk persentase pada siklus II sebesar $75,8 \%$.

5) Jari-jari tangan dirapatkan dan dipukulkan pada bola tepat pada telapak tangan.

Pada siklus I hasil rata-rata yang diperoleh pada gerkan ini sebanyak $69,7 \%$. Kesulitan dalam gerakan ini terlihat pada perkenaan bola dengan telapak tangan, kebanyakan siswa melakukan gerakan ini mengenai ujung telapak tangan. Usaha yang dilakukan dalam meningkatkan gerakan ini memberikan latihan terpisah tanpa melakukan lompatan sehingga akhirnya berhasil, hal tersebut dibuktikan dengan hasil rata-rata pada siklus II mengingkat menjadi 78,8\%.

6) Lentingan badan kebelakang saat tangan memukul bola.

Hasil rata-rata indikator keenam pada siklus I yaitu sebanyak $72 \%$. Persentase tersebut belum mencapai target yang ditentukan. Banyak siswa yang masih mengalami kesulitan melakukan lentingan saat tangan memukul bola. Guru memberikan latihan terpisah bagi siswa yang bisa melakukan lentingan saat memukul bola. Akhirnya pada siklus II hasil rata-rata indikator keenam mengingkat sangat signifikan menjadi $92,2 \%$.

7) Pendaratan dilakukan dengan kedua kaki secara bersamaan dan lutut mengeper.

Indikator aktivitas dalam melakukan gerakan pendaratan dengan kedua kaki secara bersamaan dan lutut mengeper masih sulit dilakukan sehingga terlihat hasil persentase pada siklus I sebesar 75\%, hal ini karena masih banyak siswa yang ragu menentukan kaki untuk melakukan pendaratan dan siswa juga masih banyak yang lututnya terlihat kaku. Sehingga pada siklus II guru melakukan tindakan untuk memperbaiki dengan cara memberikan contoh sesama temannya yang sudah bisa melakukan gerakan tersebut. Akhirnya indikator ke tujuh pada siklus II meningkat sehingga dapat mencapai hasil rata-rata $92,4 \%$.

Pendekatan gaya mengajar latihan power tungkai dengan menggunakan modifikasi bola gantung layak diterapkan karena dapat meningkatkan hasil belajar siswa, selain itu penggunaan modifikasi bola gantung membantu mempermudah siswa dalam melakukan gerakan Smash bola voli. Namun terdapat beberapa siswa yang belum tuntas. Hal ini dikarenakan siswa tersebut tidak mencapai indikator proses pembelajran. Siswa merasa kurang memahami gerkan tersebut, sehingga siswa lebih memilih melakukan sekedarnya saja. Kemudian ketika guru meminta siswa untuk maju kedepan melakukan gerakan siswa justru saling tunjuk. Sama halnya dengan hasil pembelajaran, pada hasil belajarnya pun terdapat beberapa siswa yang belum tuntas. Hal ini dikarenakan dibandingkan dengan siswa yang lain, terdapat beberapa siswa yang sedikit lambat untuk memahami materi pembelajaran.

Meski demikian, secara keseluruhan disimpulkan bahwa pendekatan gaya mengajar latihan power tungkai dengan menggunakan modifikasi bola gantung dapat meningkatkan hasil belajar siswa. Hal ini sesuai hasil observasi yang dilakukan peneliti selama proses pembelajaran berlangsung. Terbukti persentase hasil belajar siswa pada siklus I sebesar $64 \%$ dan pada siklus II meningkat menjadi $91,1 \%$. Jadi dapat dipahami bahwa pendekatan gaya mengajar latihan power tungkai dengan menggunakan modifikasi bola gantung dalam prosespembelajaran bola voli dapat meningkatkan hasil 
belajar. Dengan begitu kegiatan belajar menjadi lebih aktif, dan siswa dapat lebih mudah dalam melakukan gerakan tersebut. Sesuai dengan teori Menurut Mosston, (2008:101), setiap siswa dalam sebuah kelas memiliki psikologi, sosial, dan kognitif yang berbeda-beda. Oleh karena itu sangat penting bagi guru untuk mengetahui alur kegiatan dari setiap proses pembelajaran yang akan dilakukan.

\section{SIMPULAN}

Berdasarkan hasil penelitian yang telah dijelaskan, masalah prosedur penelitian dengan menerapkan gaya mengajar latihan terhadap hasil belajar passing atas bola voli pada siswa kelas $\mathrm{X}$ SMA Negeri 5 Tanjung Jabung Barat. Maka hasil yang telah ada dapat disimpulkan hal-hal sebagai berikut: (1) perencanaan kegiatan pembelajaran pada siklus pertama dan kedua peneliti konsisten melaksanakan berbagai kegiatan pembelajaran yang disyaratkan untuk menyelenggarakan kegiatan pembelajaran yang baik, (2) peneliti dilakukan dalam dua siklus dan pada siklus ke pertama motivasi siswa cukup meningkat sesuai dengan rencana pembelajaran, hasilnya adalah 22 siswa aktif, 8 siswa kurang dan 3 siswa pasif. Berdasarkan hasil diatas pada siklus ke 1 siswa cukup antusias dalam mengikuti pembelajaran Smash bola voli. Sesuai dengan refleksi, harapan dari peneliti $66,7 \%$ siswa aktif, termotivasi, serta antusias dalam mengikuti kegiatan pembelajaran. Sehingga penilitian harus dilakukan pada tahap siklus kedua. Siklus kedua peneliti berhasil memperbaiki pendekatan pembelajaran dengan memotivasi siswa sesuai dengan kondisi siswa pada saat itu, hasilnya adalah 30 siswa aktif dalam mengikuti pembelajaran passing atas bola voli, 3 siswa bersikap kurang aktif, (3) berdasarkan hasil belajar siswa pada siklus pertama nilai rata-rata kelas pembelajaran smash bola voli adalah 73,48 dan hasil belajar siswa pada siklus kedua adalah 79,76.

\section{DAFTAR PUSTAKA}

Arsyad, Azhar. (2011). Media Pembelajaran. Jakarta: PT. Raja Grafindo Persada.

Asep Kurnia Nenggala. (2007). Pendidikan Jasmani, Olah Raga, dan Kesehatan.

Cetakan I. Bandung: Grafindo Media Pratama.

Ekawarna. (2011). Penelitian Tindakan Kelas. Jakarta: Gaung Persada (GP Press)

Penelitian Tindakan Kelas. (2013). Jakarta: Referensi (GP Press Group)

Husdarta., Yudha M. Saputra. (2000). Belajar dan Pembelajaran. Jakarta: Erlangga.

Martinis Yamin. (2007). Kiat Membelajarkan Siswa. Jakarta: Gaung Persada Press dan Center for Learning Innovation (CLI).

Mosston., Ashworth. (2009) Jurnal Spektrum Gaya Mengajar

Oemar Hamalik. (1994). Media Pendidikan. Bandung: Citra Aditya Bakti.

Sarumpaet. (1991). Teknik Dasar Bola Voli. Jakarta: Sinar Jaya 